Journal of Primary Education
$9(5)(2020): 511-517$
UNNES
https://journal.unnes.ac.id/sju/index.php/jpe

\title{
Mathematics Creative Thinking Skills in Problem-Based Learning Model Reviewed from Learners' Curiosity and Gender
}

\author{
Mustofa Arifin $^{1 凶}$, Hardi Suyitno $^{2}$, Nuriana Rachmani Dewi (Nino Adhi) ${ }^{2}$ \\ DOI: https://doi.org/ 10.15294/jpe.v9i5.43223 \\ ${ }^{1}$ Prodi Pendidikan Matematika Pascasarjana Universitas Negeri Semarang, Indonesia \\ ${ }^{2}$ Pascasarjana, Universitas Negeri Semarang, Indonesia
}

\begin{abstract}
Article Info
Abstract

History Articles

Received:

20 September 2020

Accepted:

18 October 2020

Published:

31 December 2020

Creative thinking skills are important to be trained in mathematics learning because solving math problems cannot be separated from these skills. This research described learners' mathematics creative thinking skills reviewed by curiosity and gender. This research is sequential explanatory research with a mixed methods with quantitative and qualitative approaches. Thirty-five learners of the 10th graders learning group were given a curiosity test to discover their curiosity types. They were stimulated by problem-based learning

Keywords:

Creative Thinking

Skill, Problem Based

Learning, Curiosity,

Gender

to develop their mathematics creative thinking skills. The findings showed that learners had various mathematics, creative thinking skills. They were proven by epistemic, perceptual curiosity, and perceptual curiosity diverse learners for both males and females. They were creative. The male learners with epistemic curiosity diverse categories were also creative while the female was very creative. Based on this research, the mathematical creative thinking ability of female gender students with the epistemic curiosity type is more dominant than perceptual curiosity.
\end{abstract}

\footnotetext{
Correspondence address:

Jalan Pramuka Rt 03 Rw 03 Bobotsari Purbalingga, Jawa Tengah

53353, Indonesia

E-mail: mustofamath08@gmail.com
}

p-ISSN 2252-6404

e-ISSN 2502-4515 


\section{INTRODUCTION}

Mathematics, creative thinking skill is required in learning mathematics because learning mathematics should emphasize creativity. Rumasoreng (2014) found that the difficulty level order also occurred in psychomotor, conceptual, and principal difficulties.

The most important aspect to consider while learning mathematics is - learners' affective skills. One of them is curiosity. Herayani (2015) found that curiosity and mathematics creative thinking skills positively influenced mathematics, creative thinking skills.

Based on the observations on Islamic Senior High School learners in the academic year of 2017/2018, in Purbalingga, the difficulties were such as (1) conceptual implementation of trigonometry comparison such as to mention the definition of sinus alpha, cotangent alpha, cosecant alpha, and secant alpha; (2) to apply the principles due to their lack understanding of the basic concept and to use related angles; and (3) to solve verbal question forms, such as in understanding the words of the questions and lack of problemsolution plan management. Therefore, this research attempted to determine the learners' mathematics creative thinking skill reviewed from curiosity and perceptual curiosity on both male and female learners of the schools. Four indicators of mathematics creative thinking skills applied were: (1) fluency, (2) flexibility, (3) originality, and (4) elaboration.

The learners were also found to lack conceptual trigonometry mastery. They did not master several matters, such as the value of special angles and the given formula implementation. They also could not solve the algebraic operation such as root and fractional simplification. It was due to the learning emphasis on the outcome rather than the learning process. Thus, learners tended to memorize the concepts and the trigonometry formulas repeatedly without understanding the points and the essences.
Open-ended questions in learning mathematics would provide more opportunities for learners to develop their mathematics competencies (Takahashi, 2008; Ramadhani, 2017). Subyan in Mahmudi (2008); Suriani (2015); Saironi (2017); and Wijaya (2018) also argued that strategies of how materials are shared should be based on open-ended perception. Thus, it takes problem-based learning that is begun by providing problems for learners. Thus, it could be concluded that the open-ended question model could motivate learners to find various alternative solutions to solve mathematics problems.

Dealing with fact found in previous research, lower mathematics creative thinking skills could be caused by several factors, such as the applied learning process (Sincubba et al., 2017). The problem-based learning model provides learners with real-life problems to invoke their activeness, train, and develop their mathematics creative thinking skills.

In his research, Johnson (2003) found that if learners had been given opportunities to train their thinking skills, they could develop a habit to differ between the right thing and the bad thing. They could also differ in assumption, reality, fact, opinion, knowledge, and belief. Therefore, an individual should have creative thinking skills and curiosity to easily engage and solve problems (Santoso, 2011; Solehuzain \& Dwidayati, 2017).

Creative thinking skills and curiosity could develop an individual decide or judge something. Thus, he could solve the problems. Mathematics, creative thinking skills, and curiosity are important. However, unfortunately, Indonesian learners had not been able to master them. It included the learners of Islamic Public Senior High School Purbalingga.

This research was begun by giving a curiosity questionnaire sheet for the experimental group learners. It had a purpose to group the learners based on curiosity characteristics. The results showed Epistemic Curiosity (EC) and Perceptual Curiosity (PC) learners' categories. The analysis results of the curiosity questionnaire were used to determine 
the research subjects. In every category, four subjects were selected. They were two male and two female learners to be analyzed comprehensively in terms of their creative thinking skills.

The researcher then applied mathematics learning on triangle material with a problembased learning model for the experimental group. It was done within six meetings. During the activity, learners were habituated to solve the questions based on creative thinking skill indicators.

At the end of the meeting, the learners' mathematics creative thinking skills were tested. After providing a mathematics creative thinking skill test (MCTST), the subjects were then interviewed. This research aimed to find out more about how learners solved the test.

Based on the formulation of the problem above, the purpose of this study is to describe students' mathematical thinking skills in terms of gender and curiosity.

\section{METHOD}

This research applied mixed method with sequential explanatory design. This method collects and analyzes data quantitatively in the first place and then qualitatively (Rahma, 2016; Rohman, 2016; Berman, 2017; Triyani: 2019).

Quantitative indicators are obtained from the results of tests of students' mathematical creative thinking abilities with criteria including fluency, flexibility, originality, and elaboration. Then the qualitative indicators in this study were obtained from the results of the interview results of the mathematical creative thinking ability test and the type of student curiosity in terms of gender.

This research was carried out in Purbalingga Islamic Public Senior High School. It was done by having the quantitative stage. The population consisted of all $\mathrm{X}$ Science learners. The samples were from the $\mathrm{X}$ science 4 learning group as the experimental group and $\mathrm{X}$ science 5 learning group as the control group. The data collection was done through observation, test, and subject - interview techniques (Widyaswara, 2019; Safitri, 2020).

Dealing with quantitative data, the used sample consisted of an experimental group and a control group. Both groups were given a posttest of creative thinking skills. However, only the experimental group (a) was taught by the problem-based learning model (Creswell, 2014). On the other hand, the qualitative data stage took two learners for each high, moderate, and low category. They were then quantitatively analyzed by applying a prerequisite test and final data analyses. The prerequisite test was taken from the creative thinking skill test. The purpose was to find out the data normality.

On the other hand, the final data test was taken from the learners' works in the form of the final creative thinking skill test, the questionnaire result, and the interview results dealing with the learners' mathematics creative thinking skills. The learners' creative thinking skill test results functioned as the main data source of the quantitative stage. Meanwhile, the qualitative stage used the data source from the test answers, the questionnaire results, and the interview. Meanwhile, the qualitative data analysis used three steps: data reduction, presentation, and conclusion.

\section{RESULT AND DISCUSSION}

The results were grouped into two criterias, the problem-based learning quality toward learners' mathematics creative thinking skills reviewed from curiosity and gender, and learners' mathematics creative thinking skill descriptions reviewed from curiosity and gender.

The planning stage consisted of learning instrument arrangements, such as syllabus, lesson plan, worksheet, and mathematics creative thinking skill test. Two lecturers at the postgraduate school mathematics education study program and two mathematics teachers validated the learning instruments. The assessment applied a 1 to 5 rank scale. Here are the data from the experts and the validation results, as shown in Table 1 . 
Table 1. The Validation Results toward the Learning Instruments

\begin{tabular}{|c|c|c|}
\hline Learning Instrument & $\begin{array}{l}\text { Average } \\
\text { Score }\end{array}$ & Categories \\
\hline Syllabus & \multirow[t]{2}{*}{4.63} & Extremely \\
\hline Lesson Plan & & excellent \\
\hline Worksheet & \multirow[t]{2}{*}{4.73} & Extremely \\
\hline Mathematical & & excellent \\
\hline Thinking & \multirow[t]{2}{*}{4.70} & Extremely \\
\hline \multirow[t]{2}{*}{ Skills Test (MCTST) } & & excellent \\
\hline & 4.35 & Excellent \\
\hline
\end{tabular}

The results of the implementation stage could be observed by a problem-based learning promotion observation sheet. The learning process realization level was calculated by summing up all aspect scores. Then, they were divided by the numbers of the assessed aspects. It obtained a percentage of $83.5 \%$, meaning that the learning implementation was qualified. Dealing with the learners' response questionnaire data, from twelve question items, the maximum average score was 4 , the lowest score 2.75 , and the average score of 3.42. Thus, the responses were categorized as extremely excellent. It could be concluded that learners excellently followed this problem-based learning activity. They were enjoying and feeling comfortable, so they were motivated to learn. The results of the mathematical creative thinking skills test (MCTST) of one of the students with the epistemic curiosity type before and after learning which can be seen in the Figure 1 and 2 , respectively.

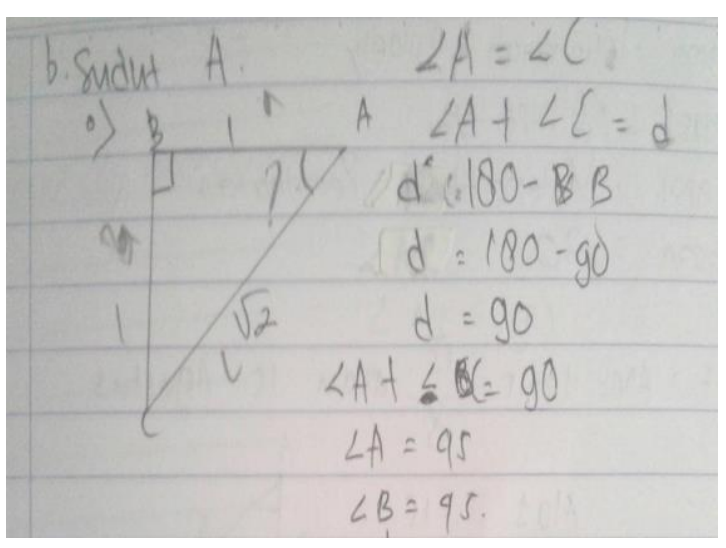

Figur 1. Students' work before learning program
Figure 1 shows that ECS students before learning problem-based learning can only provide one way for the answer and after learning (Figure 2) students give more than one way to the answer.

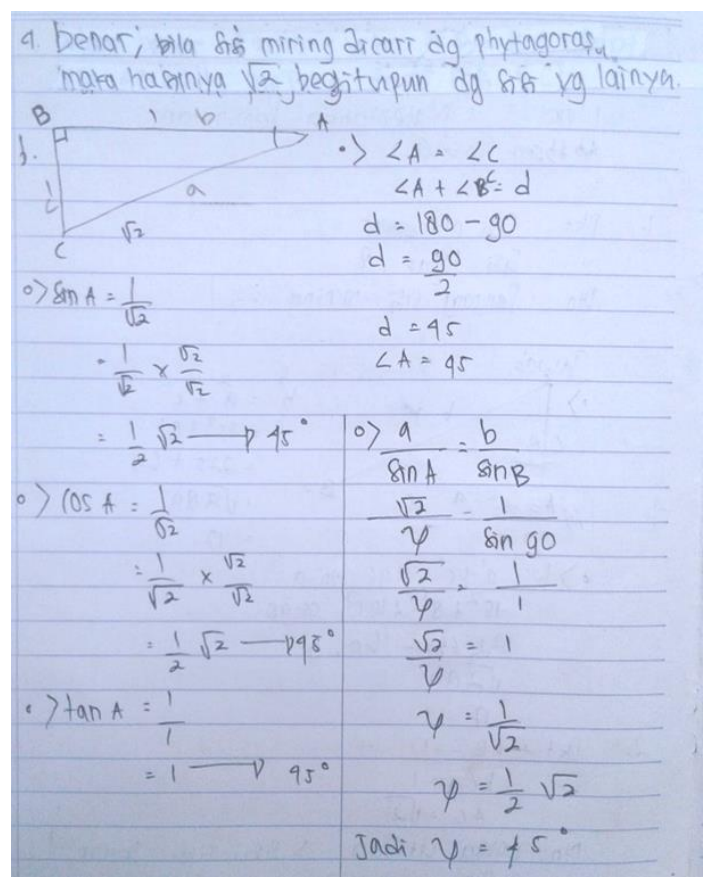

Figure 2. Students' work after learning program

This shows that there are differences before and after problem-based learning. The effectiveness, completeness, the gained improvement, and the influence tests were conducted on the evaluating stage.

Based on the individual completeness test, by using a t-test and the significant level showed $5 \%$. It was obtained from $t_{\text {count }}=6.61$ with $t_{\text {table }}=$ 1.69 , meaning that $t_{\text {count }}>t_{\text {table. }}$. Thus, $H_{0}$ was rejected, so it could be concluded that the average of students' mathematics creative thinking skills of the experimental group reached the standard of minimum mastery.

Seventy-five percent of the learners could reach the minimum mastery standard, 60, after being taught by autonomous learning assisted by the module. Then, dealing with proportional difference test, by using $\mathrm{z}$ test and a significant score of $5 \%$, the $\mathrm{z}_{\text {count }}=1.973>0.4756=\mathrm{z}_{\text {table }}$. It meant $\mathrm{H}_{0}$ was rejected. Thus, the learners' mathematics creative thinking skills taught by 
problem-based learning were better than those taught by the expository method.

Based on the effectiveness data, the effectiveness criteria on the evaluation stage had been met. These findings were consistent with Saironi (2018). He found that curiosity influenced positively toward thinking skills, specifically mathematics creative thinking skills.

The next discussion is about learners' mathematics creative thinking skills reviewed from curiosity during the learning. The referred curiosity in this research consisted of four indicators of mathematics creative thinking skills at school.

The epistemic curiosity specific character learners were E-34 and E-19. They had almost been able to solve the given problems perfectly. The reason was they had not been perfect in solving the problems. The second reason was the lack of flexibility and elaboration indicators. The average score of epistemic curiosity specific learners was 60.42. Mathematical creative thinking abilities of students in the group include the creative category.

The epistemic curiosity diverse character learners were E-28 and E-20. They had almost been able to solve the given problems perfectly. The reason was they had not been perfect in solving the problems. E-28 subject had some lacks on flexibility and elaboration indicators. On the other hand, the E-20 subject had some lacks on the elaboration indicator. The average score of epistemic curiosity diverse learners was 73.44. Mathematical creative thinking abilities of students in the group include the creative category.

The perceptual curiosity specific character learners were E-24 and E-01. They had almost been able to solve the given problems perfectly. The reason was they had not been perfect in solving the problems. E-24 and E-01 subjects had not been able to master the flexibility indicator. However, it was found in different questions. The average score of perceptual curiosity specific learners was 69.20. Mathematical creative thinking abilities of students in the group include the creative category.
The perceptual curiosity diverse character learners were E-02 and E-16. They had almost been able to solve the given problems perfectly. The reason was they had not been perfect in solving the problems. E-02 and E-16 subjects had not been able to master flexibility indicators. However, in other indicators, such as originality, only E-02 had not mastered it. On the other hand, dealing with the elaboration indicator, E16 had not mastered it. The average score of perceptual curiosity diverse learners was 79.79. Mathematical creative thinking abilities of students in the group include the creative category.

The results showed that learners had various mathematics, creative thinking skills. They were proven by epistemic, perceptual curiosity, and perceptual curiosity diverse learners for both males and females. They were creative-the male learners with epistemic curiosity. Diverse gender categories were also creative, while the female with epistemic curiosity diverse gender was very creative.

Based on students with low curiosity had low critical thinking skills than those with high curiosity. The findings were in line with Solehuzain (2017). He states that learners' creative thinking skills and curiosity must be owned to easily engage problems and solve them. Dealing with the stimulus of problembased learning, it was proven capable of improving learners' mathematics skills. This results were in line with Cahyaningsih (2015), Dwiyanto (2017); Fauziyah (2017); Arismawati (2017); and Atiningsih (2018).

The novelty of this study, compared to other studies, is that female gender with the epistemic diversive type could think creative mathematically which is more dominant than male gender, both epistemic and perceptual types. This can be seen in the results of the mathematical creative thinking ability of female gender students with the epistemic diversive type with the category of mathematical creative thinking ability in the very creative category. 


\section{CONCLUSION}

The findings showed that learners had various mathematics, creative thinking skills. They were proven by epistemic, perceptual curiosity, and perceptual curiosity diverse learners for both males and females. They were creative. The male learners with epistemic curiosity diverse categories were also creative while the female was very creative. Based on this research, the mathematical creative thinking ability of female gender students with the epistemic curiosity type is more dominant than perceptual curiosity.

\section{REFERENCES}

Arismawati, U. \& Bondan, D. (2017). Efektivitas Model Pembelajaran Problem Based Learning ditinjau dari Kemampuan Pemecahan Masalah dan Kepercayaan Diri Siswa Kelas VII SMP Negeri 1 Sanden, Yogyakarta. Universitas Negeri Yogyakarta: Jurnal Pendidikan Matematika. 6(9): 9-19.

Atiningsih, S.M. (2018). Penerapan Model Problem Based Learning untuk Meningkatkan Tanggung Jawab dan Kemampuan Koneksi Matematika Peserta Didik Kelas XI. IKIP Veteran Semarang: Journal of Medives. 2(1):77-86.

Berman, E.A. (2017). An Exploratory Sequential Mixed Methods Approach to Understanding Researchers' Data Management Practices at UVM: Integrated Findings to Develop Research Data Services. University of Vermont: Journal of Science Librarianship. 6(1), 1-24.

Cahyaningsih, R., \& Asikin, M. (2015). Comparison Of Creative Tinking Ability To Use Student Learning Mathematics Mathemaatical Humanistic and Problem Based Learning in The Training Model Setting INNOMATTS. Universitas Negeri Makasar: Jurnal Nalar Pendidikan. 3(1):24-29.
Dwiyanto, F., Setyosari, P., \& Wahjoedi, Dwiyogo, W.D. (2017). Effects of Problem Based Learning Strategy and Achievement Motivation on the Student's Critical Thinking Abilities. International Journal of Science and Research. 6(6): 707713.

Fauziyah, L., \& Kartono. (2017). Model Problem Based Learning dengan Pendekatan OpenEnded untuk Meningkatkan Kemampuan Pemecahan Masalah Siswa. Universitas Negeri Semarang: Unnes Journal of Mathematics Education Research. 6(1): 59-67.

Rahma, A. D., Sulhadi., \& Sumarti, S. (2016). Implementasi Pembelajaran Sains Dengan Media Fotonovela Untuk Meningkatkan Motivasi Belajar Siswa SD/MI. Universitas Negeri Semarang: Journal of Primary Education. 5(1): 1 - 9 .

Ramadhani, D., \& Nuryanis, N. (2018). Analisis Kemampuan Berpikir Kreatif Matematis Siswa SD Dalam Menyelesaikan OpenEnded Problem. Universitas Ahmad Dahlan: Jurnal Pendidikan Sekolah Dasar. 4(2): 54 - 62.

Rohman, M. G., Mulyono,\& Dwidayati, Nurkaromah. (2016). Kemampuan Aljabar Siswa Dalam Pembelajaran Team Assisted Individualization (TAI) Dengan Pendekatan Saintifik Universitas Negeri Semarang: Unnes Journal of Mathematics Education Research. 5(1): 9-16.

Rumasoreng, M. I., \& Sugiman, S. (2017). Analisis Kesulitan Matematika Siswa SMA/MA Dalam Menyelesaikan Soal Setara UN Di Kabupaten Maluku Tengah. Universitas Negeri Yogyakarta: Jurnal Riset Pendidikan Matematika. 1(1): 22-34.

Saironi, M., \& Sukestiyarno, YL. (2017). Kemampuan Berpikir Kreatif Matematis Siswa dan Pembentukan Karakter Rasa Ingin Tahu Siswa pada Pembelajaran Open Ended Berbasis Etnomatematika. Universitas Negeri Semarang: Unnes Journal of Mathematics Education Research. 6(1): $76-88$ 
Solehuzain., \& Dwidayati, N, K,. (2017). Kemampuan Berpikir Kreatif dan Rasa Ingin Tahu pada Model Problem-Based Learning dengan Masalah Open Ended. Universitas Negeri Semarang: Unnes Journal of Mathematics Education Research. 6 (1): $103-111$.

Suriyani. (2015). Peningkatan Kemampuan Berpikir Kreatif Dan Kemandirian Belajar Siswa Melalui Pembelajaran Matematika Dengan Pendekatan Open-Ended. Universitas Labuhan Batu : Edu Science. 2(2): $28-34$.

Suyitno, A., Suyitno, H., Rochmad, \& Dwijanto. (2017). Use of open-ended problems as the basis for the mathematical creativity growth disclosure of student. Journal of Physics: Conf. Series 983 012110: 1 - 5 .

Triyani, E., Putra, N. M. D., \& Alimah, S. (2019). Contextual Learning by Local
Wisdom to Improve The Understanding of Simple Machine Concept. Universitas Negeri Semarang: Jurnal Profesi Keguruan. 5(1): 96-101.

Widyaswara, I. B., Wardono., \& Asih, T. S. N. (2019). Mathematical Literacy Ability Viewed from Student Engagement on Formulate Share Listen Create Model with Reciprocal Teaching Approach Assisted by Edmodo Unnes. Universitas Negeri Semarang: Journal of Mathematics Education Research. 8(2): 188 - 194.

Wijaya, A. (2018). How do open-ended problems promote mathematical creativity? A reflection of bare mathematics problem and contextual problem. Journal of Physics: Conf. Series 983 012114: 1 - 6 . 